\title{
Impact of Brand Image and Brand Loyalty in Measuring Brand Equity of Islami Bank Bangladesh Ltd.
}

\author{
Mohsina Fatema1, Md. Abul Kalam Azad², Abdul Kadar Mohammad Masum³ \\ ${ }^{1}$ Lecturer in Marketing, Department of Business Administration, International Islamic University of Chittagong, BANGLADESH \\ ${ }^{2}$ Assistant Professor of Finance, Department of Business Administration, International Islamic University of Chittagong, BANGLADESH \\ ${ }^{3}$ Assistant Professor of IT, Department of Business Administration, International Islamic University of Chittagong, BANGLADESH
}

\begin{abstract}
This paper aims at investigating the interrelation between brand image and brand loyalty in case of measuring brand equity of Islami Bank Bangladesh Ltd. Brand Image (BI) and Brand Loyalty (BL) have been considered as the most attributing features of Brand Equity. Handful of researches have resulted these two as primary factor (Latent Variable) of Brand Equity. With this association, this study is designed at conducting research for explaining intermediating role of BI and BL over Brand equity of Islami Bank Bangladesh Limited (IBBL) using Structured Equation Modeling (SEM). Specifically, to analyze the impact of observed variables over un-observed variable e.g. BI and BL we have used Confirmatory Factor Analysis. Only primary data was used for the study which was collected through structured questionnaire from a total number of 399 customers' located in 43 branches of IBBL within Dhaka city. Simple Random Selection (SRS) was followed for sampling design. Findings of the study show that a positive correlation exists between BI and BL for IBBL. Moreover, strong influence of Brand Loyalty over Brand Equity was found that of Brand Image in case of IBBL. The model fit of the study strongly signify the result as successful estimate of the model.
\end{abstract}

Keywords: Brand equity; Brand image; Brand loyalty.

\section{INTRODUCTION}

$\mathrm{B}$ rand image is the combined effort of brand name in consumer's memory that is linked with other brand attributes (Keller, 1993).It consists of functional and symbolic brand beliefs. Islamic Branding has been able to create positive image in the financial sectors with its interest free banking i.e. Halal banking which got great popularity and success for their long built image and reputation. There are about 500 Islamic financial institutions worldwide (the banker, 2007) which is the reflection of their long built positive brand image. Their asset is growing at over 30 percent annually since 2000 and is set for continued strong growth. According to Nabeel Shoaib, global head of HSBC Amanah, the Islamic finance industry is rapidly evolving and expanding, with growth of banking assets estimated at $\$ 750 \mathrm{bn}$ and growing at a rate of $15 \%$ to $20 \%$ a year. Several studies suggest that, not only the Muslims but the non-Muslims has also reported that, Islamic Brands like Halal products are of increasing demand to Non- Muslims as well because of its high performance, safety and proven benefit of their product and services.

The main objective of this study is to examine the impact of brand image and brand loyalty on brand equity. The paper begins with a review of the relevant literatures to develop a conceptual frame work. Then the hypotheses are developed for testing and illustrate the empirical approach and data collection. Finally, implication of the findings are discussed and concluded with some recommendations.

Copyright ( 92013 , Asian Business Consortium | ABR

\section{THEORETICAL BACKGROUND AND HYPOTHESES}

\subsection{BRAND EQUITY (OBE):}

Brand equity is the amount the brand is worth to the owner. Aker (1991) defined it as 'a set of assets and liabilities linked to a brand, its name and symbol, which adds to or subtracts from the value provided by its product or service to affirm and/ or to that firm's customers.' There are two tiers of measuring brand equity; one is firm based brand equity and consumer-based brand equity (CBBE). This study is conducted on CBBE approach, as it offers insights into consumer behavior which is convertible into actionable brand strategies (Keller 1993). According to Keller (1993, p2), CBBE is the "differential effect of brand knowledge on consumer response to the marketing of the brand." From this concept it is deduced that, a brand is positively valued when the consumer reacts more favorably to the marketing of product with a known brand name. (George, Oliver and Temi, 2006). From the past study, it has been found that the brand with greater market share yielded substantially higher levels of brand acceptability. On the other hand, the brand with higher image in the category generated significantly greater preference (Enayet, 2007). This study will fill the gap to find out the effects of brand image on brand loyalty which is affecting brand equity.

\subsection{BRAND IMAGE (BIM):}

Brand image as defined by Keller is the Perception about a brand as reflected by the brand associations held in consumer memory while brand associations are the other 
informational nodes linked to the brand node in memory and contain the meaning of the brand for consumers. Brand awareness affects consumer decision making by influencing the formation and strengthening of brand associations in the brand image. (Keller, 2011) Image of the Corporate that has tradition, ideology, business name, reputation, variety of services, which ultimately increasing customer's interactions for impression of quality communication (Solomon, 1985). Corporate image also affects customer's expectation with regard to the quality of the service offered (Yoon, 1993). Berens and Van Riel, (2004) identified three main conceptual streams relating to corporate associations. These are social expectations people have regarding the organization; the corporate personality traits that people have toward a company; and the degree of trust toward the company.(Davis, 2004) identified that the corporate character scale mirrored the product brand personality traits. Helm(2005) stated that corporate image composed of ten elements:1)Quality of products; 2) Commitment to protecting the environment; 3) Corporate success;4)Treatment of employees; 5)customer orientation; 6) commitment to charitable and social issues; 7)Value for money of products;8) Financial performance;9) Qualification of management; and 10) Credibility of advertising claims. Building corporate image is a long run process which may be improved by technological breakthrough. A company needs to identify its image strengths and weaknesses on key attributes of each target group and to take corrective actions to better its image (Barich \& Kotler, 1991). In our survey, the target customers are mainly Muslims, who share a common faith and pose reflection of their belief in case of their purchase behavior. Consumers buy products correlating certain memories and feelings and wish to depict certain image out of it (Varlegh \& Steenkamp, 1999). Since religiosity guides the basic purchasing pattern (McDaniel \& Burnt, 1990), it has impact in financial transaction as well.

Therefore, this paper proposes the following hypotheses:

H1: Brand Image has significant positive influence for measuring brand equity.

\subsection{BRAND LOYALTY (BL):}

One of the prominent components of brand equity is brand loyalty, which implies that the consumers have a good attitude towards a particular brand over other competitors (Kambiz, Leila, 2012). When brand loyalty is increases, the brand's equity/value will increase too. Brand loyalty is similar to the consumers' brand commitment (Assel,1998;Founier,1998) and is also the outcome of trust.(Moorman. Christine, Gerald and Rohit,1992) Organizations gain competitive advantage in having high rate of loyal consumers (Mellens, M, Dekimpe,1996) thus the concept of loyalty helps companies better manage customer relationship management in order to create long-term investment and profitability ( Samadi, Yaghoob, 2009).

Brand loyalty is a repurchase commitment that promises consumers will repurchase their favorable brands in the

Copyright (C) 2013, Asian Business Consortium | ABR future and will not shift their loyalty under any situation (21) there are some researchers who mentioned that positive feelings produce purchase intention. The repeat purchase behavior (brand loyalty) is also driven by the religiosity (i.e. here religious image) (LaBarbera \& Stern,1990).As Muslims who strongly comply with Shariah (Islamic) rulings, would never even go for any other brands even those prompting attractive offers.

Therefore the researchers propose the hypotheses: H2: Brand Image has positive relationship with brand loyalty.

Consumer Decision making through positive brand image and loyalty.

Aaker and Keller (1990) mentioned that a brand with high awareness and good image promotes brand loyalty to consumers, and higher the brand awareness is, the higher brand trust and purchase intension for consumers (Aker and Keller,1990). For a consumer to buy a brand positive attitude must be considered first, but brand attitude cannot be formed and intention to buy cannot occur unless brand awareness occurs (Rossister \& Perey, 1991).Consumer thus, may employ heuristics(decision rule) to buy only familiar, well-established brands( Keller, 1993)

H3: There is a significant positive relationship between brand Image and brand loyalty for consumer decision.

\section{Methodology}

Factor analysis is a widely used statistical tool to test reliability and validity of any measurement scale (Carmines \& Zeller, 1979). Research approach of this paper is inductive in nature. We used Confirmatory Factor analysis wish unstructured model to test the impact of Brand Image (BI) and Brand Loyalty (BL) of Islami Bank Bangladesh Ltd over its Brand Equity. Theoretical analysis has been shown in the earlier part stating the empirical results of different studies to run the analysis. A number of eight (08) observed variables have been selected from the cross study of different related articles. Here, the latent variables e.g. BI and BL have tested to find the correlation between them.

Data used in the study are solely primary in nature. Only Dhaka city is considered for collecting data. IBBL has total 43 branches in Dhaka City. Ten customers from each branch have been selected using Simple Random Sampling (SRS) techniques. A total number of 399 customers have been successfully interviewed and used for the study. Structured questionnaire was given to fill out consisting of both demographic and primary data. The survey questionnaire consisted of items for measuring the dimensions of brand equity, and overall brand equity. Brand equity items were developed from existing scales to measure the seven constructs on a five-point Likert scale ( $1=$ Low score of agree to $5=$ strongly agree) as suggested by Anderson and Gerbing (1988).

Descriptive study was conducted using Statistical Package for Social Science (SPSS) V-20. Inferential statistics e.g. confirmatory factor analysis was calculated using AMOS V-2.1. Cronbach's Alpha was used to test the reliability of the study. Adequacy of sampling was evaluated using 
Kaiser-Meyer-Olkin (KMO) measurement.

\section{Analysis of Descriptive Statistics}

Often, only Cronbach's Alpha $(\alpha)$ (Cronbach, 1951) indicates internal consistency of data set. Even though $\alpha$ is affected by the number of items in a scale Nunally (1967) suggested that a value of Alpha higher than 0.70 could be adequate. The scale statistics show overall score was 0.913 demonstrates consistency of the observed variables.

Kaiser-Meyer-Olkin (KMO) measurement in Table 01 resulted 0.916 and signify satisfactory sampling adequacy for testing farther factor analysis. Bartlett's Test of Sphericity was also tested which results positive Chi-Square with significant level of $0 \%$.

Table 01

\begin{tabular}{|c|c|c|}
\hline \multicolumn{3}{|c|}{ KMO and Bartlett's Test } \\
\hline $\begin{array}{l}\text { Kaiser-Meyer } \\
\text { of Sampling A }\end{array}$ & $\begin{array}{l}\text { kin Measure } \\
\text { quacy. }\end{array}$ & .916 \\
\hline $\begin{array}{l}\text { Bartlett's Test } \\
\text { of Sphericity }\end{array}$ & $\begin{array}{l}\text { Approx. Chi-Square } \\
\text { df } \\
\text { Sig. }\end{array}$ & $\begin{array}{r}3602.573 \\
300 \\
.000\end{array}$ \\
\hline
\end{tabular}

\section{Confirmatory Factor Analysis AND Findings}

The overall model fit appears quite good. The $\chi 2$ test yields a statistic of Chi-square $=23.630(\mathrm{df}=12)$, which has a corresponding p-value of .023. This p-value is convincingly high to reject the null hypothesis of a good fit. The RMSEA of .049 and CFI of .982 also suggest that the model fits the data well.

Fig:01

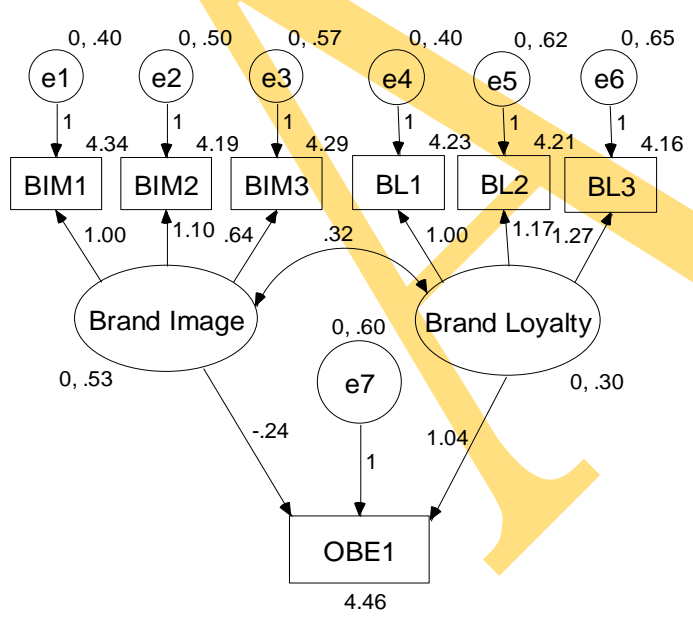

Minimum was achieved

Chi-square $=23.630$

Degrees of freedom $=12$

Probability level $=.023$

Figure 01 depicts that the correlation between Brand Loyalty and Brand Image scored .32 signify that they are strongly correlated and hence, rejected the hypothesis of Brand Image and Brand Loyalty has no correlation between them.
6 MAXimum LikeliHood Estimates

\subsection{Regression WeightS: (GRoUP NUMBER 1 - DefaULt MODEL)}

\begin{tabular}{|c|c|c|c|c|c|}
\hline & Estimate & S.E. & C.R. & $P$ & Label \\
\hline BIM1 <- Brand Image & 1.000 & & & & \\
\hline BIM2 <- Brand Image & 1.103 & .094 & 11.743 & *** & \\
\hline BIM3 <- Brand Image & .643 & .071 & 9.007 & *⿻* & \\
\hline BL1 <- Brand Loyalty & 1.000 & & & & \\
\hline$<-$ Brand Loyalty & 1.173 & .122 & 9.592 & *** & \\
\hline <- Brand Loyalty & 1.274 & .130 & 9.813 & *** & \\
\hline OBE1 «- Brand Image & -.241 & .178 & -1.360 & .174 & \\
\hline OBE1 <- Brand Loyalty & 1.039 & .254 & 4.096 & *4* & \\
\hline
\end{tabular}

6.2 INTERCEPTS: (GROUP NUMBER 1 - DEFAULT MODEL)

\begin{tabular}{|l|rccll|}
\hline & Estimate & S.E. & C.R. & P & Label \\
\hline BIM1 & 4.338 & .048 & 89.717 & $* * *$ & \\
BIM2 & 4.193 & .053 & 78.407 & $* * *$ & \\
BIM3 & 4.292 & .045 & 95.938 & $* * *$ & \\
BL1 & 4.229 & .043 & 99.267 & $* * *$ & \\
BL2 & 4.206 & .051 & 82.312 & $* * *$ & \\
BL3 & 4.156 & .054 & 77.548 & $* * *$ & \\
OBE1 & 4.458 & .045 & 99.591 & $* * *$ & \\
\hline
\end{tabular}

6.3 CoVARIANCES: (GRoup NUMBER 1 - DefAULT MODEL)

\begin{tabular}{|l|rcccc|}
\hline & Estimate & S.E. & C.R. & P & Label \\
\hline Brand Loyalty $\leftrightarrow$ Brand Image & .317 & .040 & 7.959 & $* 4 *$ & \\
\hline
\end{tabular}

\subsection{VARIANCES: (GROUP NUMBER 1 - DEFAULT MODEL)}

\begin{tabular}{|lrrrll|}
\hline & Estimate & S.E. & C.R. & P & Label \\
\hline Brand Image & .528 & .070 & 7.579 & $* * *$ & \\
Brand Loyal- & .301 & .048 & 6.267 & $* * *$ & \\
ty & & & & & \\
e1 & .403 & .046 & 8.733 & $* * *$ & \\
e2 & .496 & .056 & 8.798 & $* * *$ & \\
e3 & .574 & .046 & 12.592 & $* * *$ & \\
e4 & .400 & .038 & 10.653 & $* * *$ & \\
e5 & .624 & .056 & 11.228 & $* * *$ & \\
e6 & .647 & .060 & 10.778 & $* * *$ & \\
e7 & .599 & .055 & 10.957 & $* * *$ & \\
\hline
\end{tabular}

Under the Regression Weights heading, the unstandardized loadings appear along with standard errors, critical ratios (test statistics), and $\mathrm{p}$-values. A critical ratio greater than 1.96 or a $\mathrm{p}$-value smaller than .05 signifies the parameter is statistically discernable from zero at the .05 significance level. Three asterisks $\left({ }^{* *}\right)$ indicate that the $\mathrm{p}$ value is smaller than .001. In this case all of the unconstrained estimates are statistically significant. 


\section{Model Fit Summary Minimization History (DefaULT MODEL)}

CMIN

\begin{tabular}{|l|r|r|r|r|r|}
\hline Model & NPAR & CMIN & DF & P & CMIN/DF \\
\hline $\begin{array}{l}\text { Default } \\
\text { model }\end{array}$ & 23 & 23.630 & 12 & .023 & 1.969 \\
\hline $\begin{array}{l}\text { Saturated } \\
\text { model }\end{array}$ & 35 & .000 & 0 & & \\
\hline $\begin{array}{l}\text { Independence } \\
\text { model }\end{array}$ & 7 & 674.469 & 28 & .000 & 24.088 \\
\hline
\end{tabular}

Baseline Comparisons

\begin{tabular}{|l|r|r|r|r|r|}
\hline Model & $\begin{array}{c}\text { NFI } \\
\text { Delta1 }\end{array}$ & $\begin{array}{c}\text { RFI } \\
\text { rho1 }\end{array}$ & $\begin{array}{c}\text { IFI } \\
\text { Delta2 }\end{array}$ & $\begin{array}{c}\text { TLI } \\
\text { rho2 }\end{array}$ & CFI \\
\hline $\begin{array}{l}\text { Default } \\
\text { model }\end{array}$ & .965 & .918 & .982 & .958 & .982 \\
\hline $\begin{array}{l}\text { Saturated } \\
\text { model }\end{array}$ & 1.000 & & 1.000 & & 1.000 \\
\hline $\begin{array}{l}\text { Independence } \\
\text { model }\end{array}$ & .000 & .000 & .000 & .000 & .000 \\
\hline
\end{tabular}

RMSEA

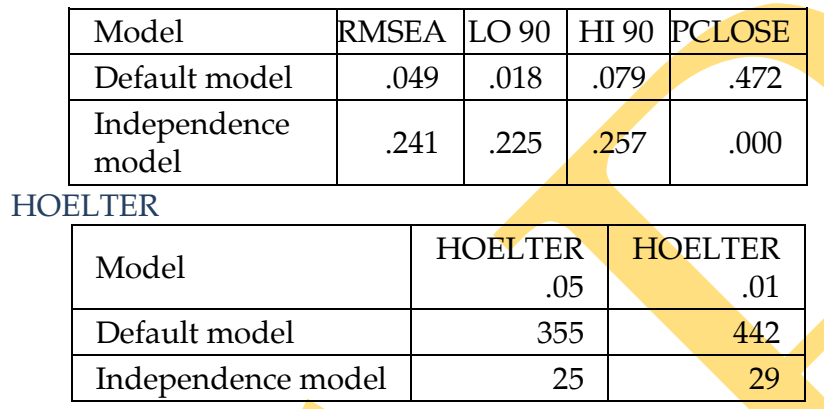

The results above signify both the significance of the model and associations of different variables with one another. One significant findings of the paper is that Brand Image and Brand Loyalty of Islami Bank Bangladesh Limited is highly correlated as shown in figure 01 scored 0.31 . Second and most valuable finding is that the paper found strong influence of Brand Loyalty than Brand Image over Brand Equity of Islami bank Bangladesh Limited.

\section{ReCOMmendations}

A big number of studies have recommended for Brand image as a major and foremost intermediary of calculating Brand Equity. Although a strong positive relation between Brand Image and Brand Equity was also found in many literatures, the specific result of the study denied the previous ones. One of the reasons might be because of not assuming all the respondents are very much aware of the service of the bank. In addition, study did not covered respondents from other city of the country. Moreover, the study did not analyze CFA with structured model. As a result, it recommends further research opportunity for the prospective researchers in the same area covering farther detailed sample size and using the structured two stage factor analysis.

\section{CONCLUSION}

A product's brand equity positively affects future profits and long-term cash flow and marketing success (Boonghee and Naveen, 2001). Brand image (BI) and Brand loyalty (BL) are found as the most attributing factors of Brand equity among many other dimensions like brand awareness, perceived quality of the brand(Mohsina, Azad and Nazneen, 2012). In this study, the authors found high correlation amongst these two major determinants of brand equity, i.e. brand image and brand loyalty. As brand loyalty implies a good attitude towards a particular brand over other competitive brands, people's purchase intention is heavily influenced by this. The result of the study may contribute to consider by the concern to get a competitive edge.

\section{LimitaTion}

One of the major limitations of this study is that, the result may not be generalized to other brands offering different kind of products, as this is done on a service company. It may be also mentioned that, this study, if done in a multicultural society would provide a different outcome. It is proposed for future researchers to test the correlation effects of other brand equity factors, as well as to study more products and services in order to get a clear understanding.

\section{REFERENCES}

Aker, D.A., \& Keller, K.L. (1990). “Consumer evaluation of brand extentions". Journal of Marketing, Vol.54 No. 1,pp 27-42.

Aker,D.A.(1991), Managing Brand equity, Free press, Newyork, NY.

Anderson, J.C. and Gerbing, D.W. (1988), "Structural equation modeling in practice: A review and recommended two-step approach", Psychological Bulletin, Vol. 103, No. 3, pp. 411-423

Assael Henry(1998), "Consumer Behaviour and Marketing Action", South-Western College Publishing, Ohio.

B.Yoo, N. Donthu, (2001), "developing and validating a multidimensional consumer-based brand equity scale", Journal of Business Research, 52, 1-14.

Carmines, E.G. and Zeller, R.A. (1979), Reliability and Validity Assessment, Beverly Hills,CA: Sage.

Enayet Hossain, 2007, “ An Evaluation of Brands Image, Product Attributes and Perceived Quality of a selected Consumer Nondurable Product', Administration and Management Review, Vo;ume 19. No.2, August 2007

Fornier, Susan (1998), Consumer and their brands: Developing relationship theory in consumer research," Journal of Consumer research, 24(March), 343-497.

George Christodoulides la Leslie de Chernatonya, Oliver Furreb, Eric Shiua and Temi Abimbolac, 2006, Jounal of Marketing Management, 799-825, ISSN0267-257X/2006/7-8/00799 +26, Western Publishers Ltd.

Kambiz H. H., \& Leila A.,(2012), “The Influence of Brand Loyalty on Cosmetics purchase Intention of Iranian Female Consumers", Journal of Basic and Applied Scientific Research, ISSN 2090-4304.

Keller, Kevin Lane, 1993 " Conceptualizing, Measuring and Managing Customer-Based Brand Equity", Journal of Marketing, Vol. 57, pp.1-22

Mellens, M., Dekimpe, M.G., \& SteenKamp, J.B.E.M.(1996), “ A Review of brand loyalty measures in marketing ", Tijdschirft voor Economic en Management, 41(4), pp. 507-533. 
Mohsina F.,Azad AK and Nazneen F.,(2012), Impact of Dimensions of Brand Equity on Islamic Financial Product:An Empirical Study on Islami Bank Bangladesh Ltd., 4 A Journal.

Moorman, Cristine, Gerald Zaltman, and Rohit Deshpande (1992), "Relationships between providers and users of market research: the dynamics of trust within and between organizations," Journal of Marketing Research, 24(August), 314-28.
Rossister J. Peryl, (1987) "Advertising and Promotional Management,"Mc Grow Hill Book. Com

Samadi M., Yaghoob-Njadi A., 2009, "A Survey of the Effect of Consumers' Perceived Risk on Purchase Intention in E-Shopping", Business Intelligence Journal. August:pp.261-275.

The top 500- Islamic financial institutions-the Bankers. Published on November 2007. 